\title{
Chinampas: An Urban Farming Model of the Aztecs and a Potential Solution for Modern Megalopolis
}

\author{
Roland $\mathrm{Ebel}^{1}$
}

AdDITIONAL INDEX wORDs. Mexico, raised fields, urban horticulture

\begin{abstract}
Summary. Urban horticulture is not as new as many people think. Throughout history, different techniques have been used to ensure sustainable urban agricultural production. A good example of this is the chinampa system, which was developed during the time of the Aztecs in the region of Lake Xochimilco, south of Mexico City. A chinampa is a raised field on a small artificial island on a freshwater lake surrounded by canals and ditches. Farmers use local vegetation and mud to construct chinampas. Fences made of a native willow [bonpland willow (Salix bonplandiana)] protect the chinampa from wind, pests, and erosion. The dominating crops are vegetables and ornamentals. The canal water that rises through capillarity to the crops reduces the need for additional irrigation. A considerable portion of the fertility in the soils is system-immanent and generated in the aquatic components of the chinampa. Complex rotations and associations allow up to seven harvests per year. Chinampas also provide ecosystem services, particularly greenhouse gas sequestration and biodiversity diversification, and they offer high recreational potential. Recently, research and community initiatives have been performed to try to recover the productive potential of chinampas and align this sustainable system with the needs of the 21 st century. In other parts of the world, some with a history of raised field agriculture, similar efforts are being made. The chinampa model could help supply food and ecosystem services in large cities on or near swamplands, large rivers, or lakes.
\end{abstract}

$\mathrm{C}$ hinampas, from the Nahuatl word chinamitl (hedge close to the reed), comprise a short stretch of land in the lakes in the southern Valley of Mexico City, where horticulture is practiced (Real Academia Española, 2018). They are also commonly called floating gardens (Ortiz et al., 2015). Chinampas describe both the region and type of intensive pre-Columbian agriculture performed in shallow lakes or marshes (Morehart and Frederick, 2014; Ramos-Bello et al., 2001; Torres et al., 1994). Chinampas are considered raised field (RF) systems, which are a type of agriculture consisting of

Received for publication 8 Feb. 2019. Accepted for publication 28 Mar. 2019.

Published online 17 September 2019

${ }^{1}$ Department of Health and Human Development, Montana State University, Reid Hall 345, Bozeman, MT 59717

This paper is a part of a workshop titled "Urban Horticulture: From Local Initiatives to Global Success Stories" that was presented 3 Aug. 2018 during the ASHS Annual Conference in Washington, DC.

R.E. is the corresponding author. E-mail: roland.ebel@gmx.com.

This is an open access article distributed under the CC BY-NC-ND license (https://creativecommons.org/ licenses/by-nc-nd/4.0/).

https://doi.org/10.21273/HORTTECH04310-19 elevated, narrow platforms used as fields surrounded by water canals connected to ditches. These fields are constructed by digging the canals and mounding the obtained earth on the platforms (Lhomme and Vacher, 2002).

The chinampa system is still practiced in suburban and inner city agriculture (Leon-Porfilla, 1992). It is one of the most intensive and productive production systems ever developed (Altieri and Koohafkan, 2004), and it is highly sustainable. Traditional chinampas are biodiverse; they can be kept in almost continuous cultivation, their soils are renewable, and they create a microenvironment that protects crops from frosts (Morehart and Frederick, 2014). In addition to their economic and environmental contributions, chinampas also provide cultural benefits to southern Mexico City (MerlínUribe et al., 2013). The role of the chinampas as a recreational resource is becoming increasingly important because the combination of tourism and agriculture has provided the impetus for a revitalization of pre-Hispanic traditions (Losada et al., 1998).

Similar RF systems were developed in other parts of the New World, but they disappeared during the colonial period; only chinampas survived (Renard et al., 2012). The chinampas of today are situated at an altitude of $2240 \mathrm{~m}$ near the lake region of Mexico City, mainly Lake Xochimilco, which is $23 \mathrm{~km}$ south of the downtown area. Xochimilco is a remnant of a formerly extensive wetland region formed by five lakes that has undergone anthropogenic alterations over the past 2000 years. Other regions near where chinampas were created, such as historical Xaltocan, have disappeared (Morehart, 2011; Narchi, 2013; Torres et al., 1994).

\section{History}

The area in the south of Mexico City has been cropped since 1500 BCE (Narchi, 2013). During the late Aztec period (1325-1521), extensive irrigation networks with floodwater systems and canals were created, which enabled the construction of the chinampas. Their development was linked to high regional population density and the growth of sizable local urban communities. Forced labor imposed by the governing elite to produce surpluses was a further trigger of agricultural intensification. The RF agriculture provided pre-Columbian farmers with better drainage, soil aeration, moisture retention during the dry season, high and long-term fertility, and high productivity per area and input (Renard et al., 2012; Torres et al., 1994).

\begin{tabular}{llll}
\hline $\begin{array}{l}\text { Units } \\
\begin{array}{l}\text { To convert U.S. to SI, } \\
\text { multiply by }\end{array}\end{array}$ & U.S. unit & SI unit & $\begin{array}{l}\text { To convert SI to U.S., } \\
\text { multiply by }\end{array}$ \\
\hline 0.3048 & $\mathrm{ft}$ & $\mathrm{m}$ & 3.2808 \\
2.54 & inch $(\mathrm{es})$ & $\mathrm{cm}$ & 0.3937 \\
1.1209 & $\mathrm{lb} / \mathrm{acre}$ & $\mathrm{kg} \cdot \mathrm{ha}^{-1}$ & 0.8922 \\
1 & $\mathrm{meq} / 100 \mathrm{~g}$ & $\mathrm{cmol} \cdot \mathrm{kg}^{-1}$ & 1 \\
1.6093 & $\mathrm{mile}(\mathrm{s})$ & $\mathrm{km}$ & 0.6214 \\
2.5900 & $\mathrm{mile}$ & $\mathrm{km}$ & 0.3861 \\
1 & $\mathrm{mmho} / \mathrm{cm}$ & $\mathrm{dS} \cdot \mathrm{m}^{-1}$ & 1 \\
62.5000 & $\mathrm{oz} / \mathrm{lb}$ & $\mathrm{g} \cdot \mathrm{kg}^{-1}$ & 0.0160
\end{tabular}


After the conquest, new crops were established, especially vegetables with a high tolerance for moisture such as lettuce (Lactuca sativa) or cabbage (Brassica olevacea var. capitata). The introduced livestock provided manure for fertilization. In contrast, the destruction of the Aztec political system involved the deterioration of the hydraulic control of the lake area. The second part of the 20th century was characterized by an explosion of the population of Mexico City, especially southern Mexico City. The consequences were less area for chinampas and a decrease in available freshwater. In the Xochimilco region, the chinampa area under cultivation decreased by more than $60 \%$ during the second half of the 20th century (Torres et al., 1994). Nevertheless, the system maintains high yields with relatively low inputs. Due to the introduction of conventional production techniques in the context of the Green Revolution around 1970, the chinampas of today are significantly altered compared to the Aztec ones (Renard et al., 2012).

The Aztecs in the Valley of Mexico used RF agriculture to exploit the swamplands bordering lakes. Similar historical arrangements were built in other regions (Altieri and Koohafkan, 2004). Systems in Tlaxcala, Mexico (Crews and Gliessman, 1991), the ancient raised gardens near Lake Titicaca (Erickson, 1992), and RF in southern China and Oceania (Renard et al., 2012) show close similarities with the chinampas. There are also analogies with RF in other parts of Latin America, Asia, Oceania, and Africa (Table 1). Less similar RF systems existed in the Netherlands, Denmark, Russia (Groenman and van Geel, 2017), France (Hortillonnages d'Amiens, 2018), and Bangladesh (Food and Agriculture Organization of the United Nations, 2018).

\section{Chinampas today}

Threatened by the quick growth of Mexico City and its suburbs, chinampas have disappeared from most of the urban landscape (Altieri and Koohafkan, 2004). Between 1989 and 2006, urban land increased from $46.7 \%$ to $57.2 \%$ of the total area in Xochimilco (not including illegal housing), and the space for chinampas decreased from $7.4 \%$ to $2.5 \%$.
Around 1990, the local government promoted the use of greenhouses due to their independence of precipitation. Consequently, the greenhouse area increased from $0.02 \%$ to $2.3 \%$ (Merlín-Uribe et al., 2013). Urbanization has caused environmental problems such as forest degradation, erosion, floods, land sinking, pollution of soil and water, reduced water retention and infiltration, and a loss of biodiversity. Farmers now deal with increasing pest populations and changes in the regional climate (Torres et al., 2000). Negative crop responses to environmental degradation include reduced flowering and fruiting, crop size reduction, and lower yields (Torres et al., 1994). Another serious threat is that the water supply, which needs to sustain the city's growing need for potable water, is decreasing (Losada et al., 1998). In 1950, the local government began supplying treated sewage water for the chinampas because many canals annually run dry. The polluted water caused soil degradation and habitat alteration. The water hyacinth (Eichbornia crassipes) currently prospers in the chinampa canals, thus making navigation difficult and inhibiting the growth of endemic flora (Torres et al., 1994).

Chinampa soils sequester large quantities of carbon (Renard et al., 2012) and are becoming a relevant strategy in Mexico City's efforts to reduce greenhouse gas (GHG) emissions. However, due to their humidity and high organic matter (OM) content, chinampa soils are characterized by considerable aerobic microbial activity and, consequently, high oxygen consumption. These conditions favor GHG emissions. A study performed in Xochimilco indicated that emissions of carbon dioxide were generally low, but that nitrous oxide contributed $90 \%$ and methane contributed $9 \%$ to GHG emissions. It was shown that frequent irrigation increases $\mathrm{GHG}$ emissions as denitrification is stimulated and anaerobic microsites are created (Ortiz et al., 2015).

\section{Dimension and construction}

Most RF systems are grouped in parallel series to form ladder- and checkerboard-like arrangements, bordered by ditches or embankments. The chinampas near Xochimilco regularly have a rectangular design. The length of the individual fields varies from 8 to $100 \mathrm{~m}$, and the width varies from 2 to $25 \mathrm{~m}$. The desired capillary effect determines the optimal dimensions: if the soil water is deficient during certain periods, then narrow fields are more convenient, and vice versa (Martínez, 2004; Renard et al., 2012). The Aztecs built their platforms to a height of 50 to $70 \mathrm{~cm}$ (Armillas, 1971). If the surface of a chinampa protrudes the water level by 45 to $65 \mathrm{~cm}$, then shallow-rooting crops can be subirrigated. For deeper rooting crops, or in soils with a high capillary rise, a minimum height of $88 \mathrm{~cm}$ is preferable (Crossley, 2004).

The first step in the construction of a chinampa is locating a firm floor in a shallow canal area. Chinampas are constructed with mud scraped from the surrounding swamps or lakes (Altieri and Koohafkan, 2004). The corners of a field are delimited by solid posts. Around each field, a fence made of ahuejotes (bonpland willow) is built. The use of this local willow species is common because it grows quickly and effectively fixes the borders of the mounds. Additionally, ahuejotes provide shade, create a protective barrier against wind and pests, and serve as trellises for vine crops. After the planting, the willow is interwoven with reeds and branches of other plants. The result is the chinamil (a solid fence) that is continuously fortified with floating mud and plant material. When the chinamil is stable and the raised mud reaches a height of $50 \mathrm{~cm}$, the top layer must dry for several weeks. Later, more mud, compost, or other organic materials are added (Martínez, 2004).

\section{Soils}

Chinampa soils are cumullic anthrosols. Clay textures are most common. Gray tones dominate when soils are dry, and black tones dominate when soils are wet. The soil density diminishes with depth, mainly because of higher OM content, which results in high aggregation and low compaction. Bulk densities are less than 1 , and the porosity reaches values of $61 \%$ to $90 \%$. Well-aerated and waterlogged soil compartments are present and vary in distribution. The soils show an alkaline $\mathrm{pH}$ of 8.3 to 8.7 in the surface, but they tend to be acidic in deeper layers, where the 
Table 1. Evidence of historical raised bed garden systems or raised-field agriculture similar to the chinampas.

\begin{tabular}{|c|c|c|}
\hline Region & Countries & Reference \\
\hline \multirow{5}{*}{$\begin{array}{l}\text { South } \\
\text { America }\end{array}$} & Peru, Bolivia (particularly near Lake & Boixadera et al., 2003 \\
\hline & Titicaca and in the Llanos de & Bruno, 2014 \\
\hline & Mojos in Bolivia) & Groenman and van Geel, 2017 \\
\hline & Colombia & Mckey et al., 2014 \\
\hline & Venezuela, Ecuador, Chile & Renard et al., 2012 \\
\hline \multirow[t]{4}{*}{ Mesoamerica } & Maya lowlands: Yucatan Peninsula, & Gliessman, 1991 \\
\hline & Tabasco, Belize, Guatemala & Mckey et al., 2014 \\
\hline & & Turner and Harrison, 1981 \\
\hline & Tlaxcala and Veracruz, Mexico & Renard et al., 2012 \\
\hline \multirow[t]{2}{*}{ Africa } & West Africa, particularly Senegal & $\begin{array}{l}\text { Denevan and Turner, } 1974 \\
\text { Iriarte et al., } 2010\end{array}$ \\
\hline & $\begin{array}{l}\text { Nigeria, Uganda, Kenya, Tanzania, } \\
\text { Zambia }\end{array}$ & Denevan and Turner, 1974 \\
\hline \multirow[t]{7}{*}{ Asia } & China & Yanying et al., 2014 \\
\hline & & Altieri and Koohafkan, 2004 \\
\hline & Central Asia & Groenman and van Geel, 2017 \\
\hline & $\begin{array}{l}\text { Burma, Malaysia, India, Vietnam, } \\
\text { Philippines }\end{array}$ & Denevan and Turner, 1974 \\
\hline & Thailand & Altieri and Koohafkan, 2004 \\
\hline & Bangladesh & $\begin{array}{l}\text { Climate Action Network } \\
\text { Southeast Asia, } 2017\end{array}$ \\
\hline & Indonesia & Renard et al., 2012 \\
\hline Oceania & $\begin{array}{l}\text { New Caledonia, Fiji, Papua New } \\
\text { Guinea }\end{array}$ & Denevan and Turner, 1974 \\
\hline
\end{tabular}

OM content is high (Ramos-Bello et al., 2001; Renard et al., 2012). Chinampa soils are generally rich in OM due to the applied lake sediments and plant residues (Ortiz et al., 2015). The subsoil is highly stratified; it contains fibric, almost wholly organic, peaty horizons, diatomite units of varying thickness, and a thin, widespread layer of reworked volcanic ash (Crossley, 2004).

The total nitrogen content ranges from 5.92 to $6.17 \mathrm{~g} \cdot \mathrm{kg}^{-1}$ (Ortiz et al., 2015). Different from other production systems, most layers of a chinampa soil are inundated for considerable periods. Waterlogging usually enhances the availability of phosphorus, making it more soluble and more diffusible. In contrast, the nitrogen availability is negatively affected. Nitrogen accumulates in the OM deposited in anaerobic conditions, and when this OM is transported to aerobic conditions, it is rapidly mineralized to nitrate (Renard et al., 2012). Nevertheless, the nutrient content and availability of an average chinampa soil are favorable for most crops; the main limitation is salinity. Chinampa soils are sodicsaline in the surface layers, and sodic, saline, and regular in deeper areas
(Ramos-Bello et al., 2001). The electric conductivity ranges from 2.79 to $6.64 \mathrm{dS} \cdot \mathrm{m}^{-1}$ (Ortiz et al., 2015). The cation exchange capacity and concentration of calcium ions $\left(\mathrm{Ca}^{2+}\right)$ are more than 60 and $90 \mathrm{cmol} \cdot \mathrm{kg}^{-1}$, respectively. Because of the alkaline $\mathrm{pH}$ and high OM and clay content, the heavy metal ion activity in solution is low because these ions are widely absorbed, fixed, or precipitated. Therefore, concentrations of heavy metals (most frequently, lead and nickel) usually do not exceed the permitted limits (Ramos-Bello et al., 2001).

\section{Drainage system and irrigation}

Traditional chinampas required the construction of complex drainage ditches and the implementation of a flood control apparatus such as a dike and sluice gates (Morehart and Frederick, 2014). Between each chinampa field, small ditches 1 to $2 \mathrm{~m}$ wide were built that connected through wide navigation channels. These canals allowed the filtering of water at the rhizosphere level of the crops; they were used for transport, irrigation, and to create water reservoirs as well as fish weirs (Martínez, 2004; Renard et al., 2012).
Most RF require two "built-in" mechanisms to provide and store water for the crops: high soil OM content provides water retention, and capillarity conducts water from the canals to the crops in an "integrated" sub-irrigation system (Renard et al., 2012). Only very particular soil and plant properties allow natural subirrigation. The width and height of the wetland fields as well as the soil type are the most critical variables. A functioning sub-irrigation system counts with a) a planting platform high enough to allow root growth; b) a subsoil composed primarily of fine sand and coarse silt to produce a capillary fringe high enough to be within the crops' rhizosphere; and c) a crop root zone that is less than 85 $\mathrm{cm}$ above the groundwater but not too profoundly reaching into the capillary fringe. In saline soils, the top of the capillary fringe should be more than $30 \mathrm{~cm}$ below the surface. The capillary fringe is commonly interspersed with abuejote roots, and subirrigation is essential for supplying moisture to the willows and the crops (Crossley, 2004).

Today, sub-irrigation is a minor factor in the overall decision-making process of the chinampa farmers, who commonly use mechanic irrigation techniques and, therefore, do not prioritize the maintenance of their fields at the appropriate height to take advantage of capillarity. Consequently, numerous chinampas are so low that waterlogging is a problem, and others exceed the maximum height to enable subirrigation. Sub-irrigation reduces the need for irrigation, but it cannot replace it. It is relevant when the onset of the rainy season is delayed or during dry years (Crossley, 2004). During the dry season, from November to May, channel water is also used to irrigate the crops (Chavarría et al., 2010). In traditional systems, canal water is scooped and splashed on the chinampa using poles and buckets. The farmer stands on the chinampa or in a canoe (Parsons, 1991). A standard tool is the zoquimatl, which is a ladle-like tool with a long handle. Currently, mechanized irrigation using buckets and hoses is most common (Crossley, 2004).

The surrounding lakes have provided enough freshwater for the 
ancient chinampas (Morehart and Frederick, 2014), but both quantity and quality of the supplied water have decreased. The water used today, which predominantly comes from a treatment plant, is partially contaminated with sodium and heavy metals. As it reaches the canals, it receives additional pollutants from household waste water, feces, and garbage due to the tourist industry (Ramos-Bello et al., 2001).

\section{Fertilization and pest and disease management}

Fertilization in the chinampas centers on the recycling of material produced within the very system. The essential nutrient source is the OM generated in its aquatic components. Farmers transfer vegetation and sediments from the bottom of the canals to the field surface, which is both a fertilization and canal maintenance measure. Under dry soil conditions, most algae, bacteria, and macrophytes die; however, when the soil remoisturizes, their populations recover immediately, and aerobic bacteria quickly mineralize the nutrients stored in the dead organisms. Algae and macrophytes exhibit "luxury consumption" of nitrogen and phosphorous, assimilating these nutrients in excess and storing them for use under nutrient-deficient conditions. Furthermore, nitrogen-fixing bacteria and cyanobacteria increase the N-reserves of a chinampa system (Renard et al., 2012). The actinorhizal association between nitrogen-fixing bacteria (Frankia sp.) and certain alders (Alnus sp.) is a further nitrogen supply (Crews and Gliessman, 1991). A significant source of $\mathrm{OM}$ is the water hyacinth, which is capable of producing up to $900 \mathrm{~kg} \cdot \mathrm{ha}^{-1}$ dry matter daily (Altieri and Koohafkan, 2004). As additional fertilization measures, chinampa farmers apply dry manure, synthetic fertilizers, crop residues, kitchen waste, ash, charcoal, and, occasionally, human excrement. The use of crop residues as mulching materials suppresses weeds (Renard et al., 2012; Torres et al., 2000).

Traditional chinampas are characterized by a high degree of biodiversity in time and space, which helps to prevent pests (Torres et al., 1994). Additionally, chinampa soils contain several fungal species that limit the proliferation of pathogens
(Renard et al., 2012). Conventional farmers also use synthetic pesticides.

\section{Agrobiodiversity}

Currently, chinampa farmers produce flowers, maize (Zea mays), legumes such as bush bean (Phaseolus vulgaris) and fava bean (Vicia fava), amaranth (Amaranthus cruentus), and at least 40 different vegetables such as tomato (Solanum lycopersicum), pepper (Capsicum annuum), lettuce, radish (Raphanus raphanistrum ssp. sativus), seepweed (Suaeda pulvinata), and purslane (Portulaca oleracea). On some chinampas, freerange animals are kept between the crops. Chickens are most common, but ducks, swine, cattle, sheep, and draught animals can also be found. Most animals are kept in small corrals and feed on the excess produce or waste from the chinampas. Their manure is incorporated into the platforms (Altieri and Koohafkan, 2004; Canabal, 1997; Clauzel, 2009; Crossley, 2004; Losada et al., 1998; RamosBello et al., 2001 ; Torres et al., $2000)$.

Vegetable and ornamental production predominate, but maize cropping, which was formerly common, has become rare. Commercial floriculture (mainly monocropping in greenhouses) prevails because it provides the highest gross returns and works in salty and infertile soils. In contrast, vegetable production is more traditional. Frequently, horticultural farmers combine cash crops with subsistent production. Most vegetables are produced in polycropping arrangements (Torres et al., 1994) and complex rotations of up to seven crops per season (Parsons, 1991). Even conventional production allows three rotations per year and up to six harvests (Canabal, 1997; Merlín-Uribe et al., 2013).

\section{Contemporary adaptations of the chinampa system}

There have been efforts to establish "modern" chinampa-like production systems in numerous countries (Table 2). The scope of these projects varies from small organic farms to large urban development projects. The first effort to revitalize chinampas started in Mexico in 1975. A former research entity of the Mexican government, the INIREB (Instituto
Nacional de Investigaciones sobre Recursos Bióticos), encouraged the construction of RF in swampy regions of the Mexican states Veracruz and Tabasco. The INIREB even hired producers from Xochimilco to guide the development of $\approx 100 \mathrm{RF}$. Among other crops, maize, rice (Oryza sativa), bush bean, alfalfa (Medicago sativa), radish, lettuce, cabbage, squash (Cucurbita sp.), and watermelon (Citrullus lanatus) were produced at two project sites. One technical mistake during project implementation was the incorrect use of dredges to construct the chinampas. These vehicles inverted the soil profile and brought infertile clay to the top and OM downward. The project in Veracruz failed from the beginning. One reason was the topdown approach of its managers who designed and implemented the project without considering the alleged beneficiaries, the local farmers. In contrast, the functionality of the chinampas in Tabasco improved over time. After a quick retreat of the officials, the project continued thanks to research and local initiatives. There is evidence of its persistence until at least the early 2000s (Altieri and Koohafkan, 2004; Burton, 2013; Chapin, 1988).

In the 1980s, a similar (combined community development and research) project was performed near Lake Titicaca, another historical RF farming region. Researchers from the University of Illinois rebuilt ancient $\mathrm{RF}$ in an area of $10 \mathrm{~km}^{2}$. Similar to the breakdown in Mexico, numerous farms were soon abandoned. However, by the 1990s, some smaller farms were still operating. The status quo of the project is uncertain. Comparable research was performed in the swampy plains of eastern Bolivia, the Llanos de Mojos (Smith, 2012). Today, in Latin America, several small organic farms are implementing the chinampa model. For example, in the Mexican state of Guanajuato, a farm produces maize and legumes in a traditional chinampa enriched with permaculture crop management (Laado, 2013).

Chinampa-like production systems have an increasing role in certain Asian countries, where they serve as a strategy to enhance both food security in poor regions and the reduction of GHG emissions. So-called floating 
Table 2. Contemporary efforts of re-interpretation of chinampas.

\begin{tabular}{|c|c|c|c|}
\hline Site & Project nature & Production system & Reference \\
\hline \multirow[t]{2}{*}{ Mexico } & $\begin{array}{l}\text { Research and community development } \\
\text { (concluded) }\end{array}$ & Traditional chinampa & Chapin, 1988 \\
\hline & Productive & "Improved" chinampa & Laado, 2013 \\
\hline $\begin{array}{r}\text { Peru and } \\
\text { Bolivia }\end{array}$ & Research (concluded) & Traditional Andean raised fields & Erickson, 1992; Smith, 2012 \\
\hline \multirow[t]{2}{*}{ Bangladesh } & Development aid & $\begin{array}{l}\text { Small floating islands built using water } \\
\text { hyacinth }\end{array}$ & $\begin{array}{l}\text { Climate Action Network Southeast } \\
\text { Asia, } 2017\end{array}$ \\
\hline & Development aid & Small floating islands on rafts & Deltsidis, 2016 \\
\hline Indonesia & Productive & $\begin{array}{l}\text { Chinampa-like transformed former } \\
\text { rice field }\end{array}$ & Denton, 2015 \\
\hline Myanmar & Productive & Chinampa-like, tomato production & Mae, 2016 \\
\hline $\begin{array}{l}\text { Congo, } \\
\text { Zambia }\end{array}$ & Productive & Unspecified & $\begin{array}{l}\text { Comptour et al., 2018; Mckey et al., } \\
\text { 2014; }\end{array}$ \\
\hline Florida & Research & Diverse floating hydroponic models & Sweat et al., 2003 \\
\hline Illinois & Recreation & Unspecified & Urban Rivers, 2018 \\
\hline Poland & Urban horticulture & Unspecified (planning stage) & City of Szczecin, 2018 \\
\hline
\end{tabular}

islands (different from chinampas because they are not fixed on the canal ground) are a common technical implementation. In Bangladesh, a project by a nongovernmental organization called Practical Action adopted the country's traditional floating gardens to provide food during periods of shortages. The RF are built using the water hyacinth as a boundary. They are $8 \mathrm{~m}$ long and $1 \mathrm{~m}$ wide. Afterward, they are covered with soil and cow manure to produce different vegetables. The initiative started in 2005 and today, despite the withdrawal of financial support, most of the project areas are still functional. The Government of Bangladesh adopted the concept, and in 2013 , it approved a large-scale project to promote floating gardening for climate change adaptation (Climate Action Network Southeast Asia, 2017). A further project in Bangladesh, funded by the University of California Davis and Tufts University, consists of floating islands placed in household fishponds to allow smallscale fish farmers to grow horticultural crops and produce seedlings. The islands are constructed from locally available materials and comprise a raft containing a soilless medium of coir and vermicompost. Flotation is provided by second-hand plastic containers attached to the bottom of the raft that can be transplanted to ground beds when the floodwater recedes (Deltsidis, 2016, 2017). At an organic farm in Bali, Indonesia, a former paddy rice terrace was transformed into a chinampa-like system
(Denton, 2015). Furthermore, traditional Sorjan production still exists in Indonesia (Renard et al., 2012). This system consists of RF where dryland crops are grown and rice is cropped in the lowered sinks (Domingo and Hagerman, 1982). The Sorjan system is also used in the Philippines (Philippine Rice Research Institute, 2016). In North America and Europe, floating gardens on rivers are becoming popular measures to increase urban biodiversity and function as recreational spots. Commonly, horticulture has a minor role. Most of the respective projects are still in the planning stage. In this regard, the city government of Szczecin, Poland, is currently developing a large-scale urban horticulture project that involves floating gardens on its main river and canals (City of Szczecin, 2018). The city government of Chicago, IL, cooperates with local initiatives, companies, and universities in the development of a park of floating gardens on the Chicago River. The focus is on recreation and re-naturalization of the river. The project is expected to conclude in 2020 (Urban Rivers, 2018). The University of Florida experiments with floating hydroponics and promotes their distribution among local horticultural producers (Sweat et al., 2003).

\section{Outlook}

Despite versatile efforts to revitalize and reinterpret chinampas, the implementation of the production system is widely limited to smallscale research and development projects. In Mexico, its origin, even with ambitious local initiatives, the outlook is alarming. A projection for the year 2057 assumes that in Xochimilco, without a concerted effort from the involved players (particularly farmers and local government), most current chinampa land will be converted to housing. Therefore, the persistence of chinampas strongly depends on the economic priorities and agricultural criteria of farmers and political interventions. Along with production, restored chinampas would provide a series of ecosystem services to Mexico City. This includes water filtration, regulation of water levels, microclimate regulation, increased biodiversity, and carbon capture and storage. Finally, RF systems increase the recreational value of a region and its economic vibrancy (Merlín-Uribe et al., 2013; Torres et al., 1994).

Mexico City could benefit from restored chinampas and similar systems, and all cities close to freshwater swampland or an adaptable lake or river might benefit also. Regions that could benefit from RF production include the Mississippi River Delta, the Hudson River Delta, extensive parts of Florida, the Great Lakes Region in the United States and Canada, the Pantanal region (Brazil, Bolivia, and Paraguay), the eastern and western Congolese swamp forests, the African Great Lakes region, eastern South Africa, Shanghai and the Yellow River Delta in China, the Kutch District and parts of the state of Kerela in India, the 
Padma River Delta and (almost all) southern Bangladesh and neighboring India, the Yangon Metropolitan area in Myanmar, extensive parts of Sumatra (Indonesia), the Mindanao River in the Philippines, the Rhone River Delta in France, Hamburg in Germany, the Mersey Delta in England, the Gulf of Finland (Finland, Estonia, Russia), and the Darwin Area and Western District Lakes near Melbourne in Australia.

The benefits of creating chinampas are not limited to big cities but also could aid smaller rural communities, especially in tropical wetlands. There, drainage of wetlands for cattle farming or paddy rice monocropping are the most common agricultural adaptations of the land, resulting in adverse environmental consequences. Furthermore, RF prevent crops from floods and offer an alternative to the clearing of tropical forest for slashand-burn agriculture. Finally, chinampas could help reduce GHG emissions and maintain tropical wetlands and their soils (Renard et al., 2012).

In conclusion, RF such as chinampas, if correctly managed, produce high yields with relatively low inputs. They also provide ecosystem services (especially GHG sequestration and increase of agrobiodiversity) and offer both recreational and socio-economic benefits to the world's megalopolis and small communities in the tropics. One limitation to their larger-scaled implementation has been high labor costs, especially for the traditional manual construction. The labor requirement could be reduced using earth-moving machines, but care must be taken to avoid compaction and inversion of the soils (Chapin, 1988; Renard et al., 2012).

\section{Literature cited}

Altieri, M.A. and P. Koohafkan. 2004. Globally important ingenious agricultural heritage systems (GIAHS): Extent, significance, and implications for development. 10 Apr. 2019. <www.fao.org/docrep/ 015/ap02le/ap02le.pdf>.

Armillas, P. 1971. Gardens on swamps. Science 174:653-661.

Boixadera, J., R.M. Poch, M.T. GarcíaGonzález, and C. Vizcayno. 2003. Hy- dromorphic and clay-related processes in soils from the Llanos de Moxos (northern Bolivia). Catena 54:403-424.

Bruno, M.C. 2014. Beyond raised fields: Exploring farming practices and processes of agricultural change in the ancient Lake Titicaca Basin of the Andes. Amer. Anthropol. 116:130-145.

Burton, T. 2013. Are Aztec chinampas a good model for food production and agrodevelopment? 12 Dec. 2018. <http://geomexico.com $/ ? \mathrm{p}=9797>$.

Canabal, B. 1997. Xochimilco una identidad recreada. Universidad Autónoma Metropolitana, Xochimilco, Mexico.

Chapin, M. 1988. The seduction of models: Chinampa agriculture in Mexico. Grassroots Dev. 12:8-17.

Chavarría, A., M.C. González, E. Dantán, and J. Cifuentes. 2010. Evaluación espacial y temporal de la diversidad de los ascomicetes dulceacuícolas del canal turístico Santa Cruz, Xochimilco, México. Rev. Mex. Biodivers. 81:733-744.

City of Szczecin. 2018. Szczecin gloating garden 2050. 11 Dec. 2018. <http://www. szczecin.eu/en/marka/brand_strategy>.

Clauzel, C. 2009. Between urban pressure and heritage: Which place for agriculture in the Chinampas of Xochimilco (Mexico)? Cah. Agr. 18:323-328.

Climate Action Network Southeast Asia. 2017. Floating gardens of Bangladesh: A community-based adaptation for combating climate change. 11 Dec. 2018. < http.www. cansouthasia.net/floating-gardens-ofbangladesh-a-community-based-adaptationfor-combating-climate-change>.

Comptour, M., S. Caillon, L. Rodrigues, and D. McKey. 2018. Wetland raisedfield agriculture and its contribution to sustainability: Ethnoecology of a presentday African system and questions about pre-Columbian systems in the American tropics. Sustainability 10:3120-3142.

Crews, T.E. and S.R. Gliessman. 1991. Raised field agriculture in Tlaxcala, Mexico: An ecosystem perspective on maintenance of soil fertility. Amer. J. Altern. Agr. 6:9-16.

Crossley, P.L. 2004. Sub-irrigation in wetland agriculture. Agr. Human Values 21:191-205.

Deltsidis, A. 2016. Innovative floating garden design to support food security in rural Bangladesh. 11 Dec. 2018. <https:// horticulture.ucdavis.edu/information/ innovative-floating-garden-designsupport-food-security-rural-bangladesh $>$.

Deltsidis, A. 2017. Innovative technologies to enhance availability of nutritious foods in Bangladesh. HortScience 52:119120 (abstr.).

Denevan, W. and B.L. Turner. 1974. Forms, functions and associations of raised fields in the Old World tropics. J. Trop. Geogr. 39:24-33.

Denton, B. 2015. Are floating gardens the ancient gardening technique of the future? 11 Dec. 2018. <http://blog.numundo. org $/ 2015 / 07 / 07 /$ bali-chinampas-amesoamerican-aquaculture-tradition-insoutheast-asia>.

Domingo, A.A. and H.H. Hagerman. 1982. Sorjan cropping system trial in irrigated wet land conditions. Philipp. J. Crop Sci. 7:154-161.

Erickson, C.L. 1992. Prehistoric landscape management in the Andean highlands: Raised field agriculture and its environmental impact. Popul. Environ. 13:285-300.

Food and Agriculture Organization of the United Nations. 2018. Floating garden agricultural practices. 7 Dec. 2018. <http:// www.fao.org/giahs/giahsaroundtheworld/ designated-sites/asia-and-the-pacific/ floating-garden-agricultural-practices/en>.

Gliessman, S.R. 1991. Ecological basis of traditional management of wetlands in tropical Mexico: Learning from agroecosystem models, p. 211-229. In: M.L. Oldfield and J.B. Alcorn (eds.). Biodiversity: Culture, conservation and ecodevelopment. Westview, Boulder, CO.

Groenman, W. and B. van Geel. 2017. Raised bed agriculture in northwest Europe triggered by climatic change around 850 BC: A hypothesis. Environ. Archaeol. 22:166-170.

Hortillonnages, d'Amiens. 2018. Histoire des hortillonnages d'Amiens. 7 Dec. 2018. $<$ http://www.hortillonnages-amiens.fr/ histoire $/>$.

Iriarte, J., B. Glaser, J. Watling, A. Wainwright, J.J. Birk, D. Renard, S. Rostain, and D. McKey. 2010. Late Holocene neotropical agricultural landscapes: Phytolith and stable carbon isotope analysis of raised fields from French Guianan coastal savannahs. J. Archaeol. Sci. 37:2984-2994.

Laado, R. 2013. Chinampas 2.0-An elegant technology from the past to save the future. 12 Dec. 2018 . <https:// permaculturenews.org/2013/05/28/ chinampas-2-0-an-elegant-technologyfrom-the-past-to-save-the-future $>$.

Leon-Porfilla, M. 1992. The Aztec image of self and society, An introduction to Nahua culture. Univ. Utah Press, Salt Lake City, UT.

Lhomme, J.P. and J.J. Vacher. 2002. Modelling nocturnal heat dynamics and 
frost mitigation in Andean raised field systems. Agr. For. Meteorol. 112:179-193.

Losada, H., H. Martinez, J. Vieyra, R. Pealing, R. Zavala, and J. Cortés. 1998. Urban agriculture in the metropolitan zone of Mexico City: Changes over time in urban, suburban and peri-urban areas. Environ. Urban. 10:37-54.

Mae, F. 2016. Floating garden in Inle Lake, Myanmar. 11 Dec. 2018. <https://www. youtube.com $/$ watch? $v=6$ YIzfP-fe68 $>$.

Martínez, J.L. 2004. Manual de construcción de chinampas. Instituto Mexicano de Tecnología del Agua, Mexico City, Mexico.

Mckey, D., D. Renard, A. Zangerlé, J. Iriarte, K.L.A. Montoya, S.S. Jimenez, and C. Raimond. 2014. New approaches to pre-Columbian raised-field agriculture: The ecology of seasonally flooded savannas, and living raised fields in Africa, as windows on the past and future. Tercer Encuentro Internacional de Arqueología Amazónica, Quito, Ecuador, 8-14 Sept. 2013. p. 73-90.

Merlín-Uribe, Y., A. Contreras-Hernández, M. Astier, O.P. Jensen, R. Zaragoza, and L. Zambrano. 2013. Urban expansion into a protected natural area in Mexico City: Alternative management scenarios. J. Environ. Plann. Mgt. 56:398-411.

Morehart, C.T. 2011. Sustainable ecologies and unsustainable politics: Chinampa farming in ancient central Mexico. Anthropol. News 52:9-10.

Morehart, C.T. and C. Frederick. 2014. The chronology and collapse of pre-Aztec raised field (chinampa) agriculture in the northern basin of Mexico. Antiquity 88:531-548.

Narchi, N.E. 2013. Deterioro ambiental en Xochimilco: Lecciones para el cambio climático global. Veredas Revista del Pensamiento Sociológico 27:177-197.

Ortiz, N., M. Luna-Guido, Y. RiveraEspinoza, M.S. Vásquez, V. Manuel RuízValdiviezo, and L. Dendooven. 2015. Greenhouse gas emissions from a chinampa soil or floating gardens in Mexico. Rev. Intl. Contam. Ambient. 31:343-350.

Parsons, J.R. 1991. Political implications of prehispanic chinampa agriculture in the Valley of Mexico, p. 17-42. In: H.R. Harvey (ed.). Land and politics in the Valley of Mexico. A two thousand year perspective. Univ. New Mexico Press, Albuquerque, NM.

Philippine Rice Research Institute. 2016. PhilRice adopts sorjan cropping system. 11 Dec. 2018. <http://www.philrice. gov.ph/philrice-adopts-sorjan-croppingsystem $>$.

Ramos-Bello, R., L.J. Cajuste, D. Flores, and N.E. García. 2001. Metales pesados, sales y sodio en los suelos de chinampa en México. Agrociencia 35:385-395.

Real Academia Española. 2018. Chinampas. 21 Dec. 2018. <http://dle.rae. es $/$ ? id $=8 \mathrm{nkbnH} 4>$.

Renard, D., J. Iriarte, J.J. Birk, S. Rostain, B. Glaser, and D. McKey. 2012. Ecological engineers ahead of their time: The functioning of pre-Columbian raised-field ag- riculture and its potential contributions to sustainability today. Ecol. Eng. 45:30-44.

Smith, M.E. 2012. Modern use of an ancient farming system. 11 Dec. 2018. $<$ http://wideurbanworld.blogspot. com/2012/09/modern-use-of-ancientfarming-system.html>.

Sweat, M., R. Tyson, and R. Hochmuth. 2003. Building a floating hydroponic garden. Univ. Florida Ext. Bul. 943.

Torres, P.T., B. Canabal, and G. Burela. 1994. Urban sustainable agriculture: The paradox of the chinampa system in Mexico City Agr. Human Values 11:37-46.

Torres, P.T., L.M.R. Sanchez, and B.I. García. 2000. Mexico City: The integration of urban agriculture to contain urban sprawl, p. 363-390. In: Growing cities, growing food, Urban agriculture on the policy agenda. Deutsche Stiftung für Entwicklung, Feldafing, Germany.

Turner, B.L. and P.D. Harrison. 1981. Prehistoric raised-field agriculture in the Maya lowlands. Science 213:399-405.

Urban Rivers. 2018. From wasted rivers to wildlife parks. 12 Dec. 2018 . <https:// www.urbanriv.org>.

Yanying, B., S. Xueping, T. Mi, and A.M. Fuller. 2014. Typical water-land utilization GIAHS in low-lying areas: The Xinghua duotian agrosystem example in China. J. Resour. Ecol. 5:320-327. 